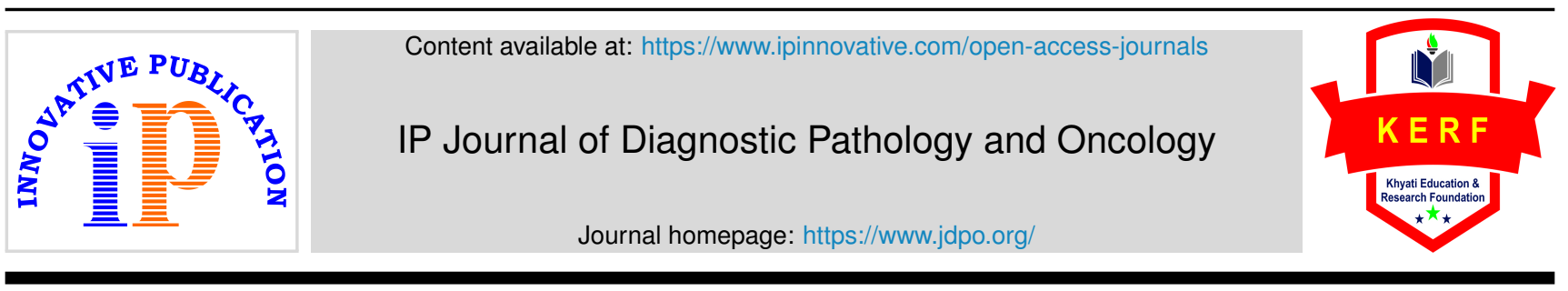

Original Research Article

\title{
A study of skin prick test to identify common allergens in allergic rhinitis patients in and around Saharanpur
}

\author{
Pooja Arora ${ }^{1, *}$ \\ ${ }^{1}$ Dept. of Pathology, Shaikh-Ul-Hind Maulana Mahmood Hasan Medical College, Saharanpur, Uttar Pradesh, India
}

\section{A R T I C L E I N F O}

\section{Article history:}

Received 14-03-2021

Accepted 16-03-2021

Available online 14-06-2021

Keywords:

Allergic rhinitis

Skin prick test

Aeroallergens

\begin{abstract}
A B S T R A C T
Background: Allergic rhinitis accounts for a significant burden of allergy in whole world. Precise identification of allergens is worthwhile since it may lead to improvement in therapy. So we conducted an observational study of common allergens by skin prick test in a group of patients.

Materials and Methods: A total of 2300 skin prick test were done using 46 common inhalant allergens on 50 patients of allergic rhinitis.

Results: Males were the predominant group of patients, and Allergic rhinitis was more common in 21- 29 years age group in our study. Frequency of positive skin prick test response to various group of allergens were- pollen (80\%), dust (70\%), mite (52\%), lnsects (50\%), fungi(48\%) and epithelial antigen(20\%).overall, pollen of parthenium $(70 \%)$ followed by house dust $(64 \%)$ were found to be the most common offending allergens.

Conclusion: Skin prick test used to identify the putative allergens is valuable to the patients for instituting avoidance therapy and immunotherapy efficiently and economically.

(C) This is an open access article distributed under the terms of the Creative Commons Attribution License (https://creativecommons.org/licenses/by/4.0/) which permits unrestricted use, distribution, and reproduction in any medium, provided the original author and source are credited.
\end{abstract}

\section{Introduction}

Allergic rhinitis being one of the commonest Allergic disorders affects $26 \%$ of the population in India. ${ }^{1}$ The prevalence of allergic rhinitis is increasing in India, possibly due to change in environment. ${ }^{2}$ More than $20 \%$ of world population suffers from $\mathrm{IgE}$ associated Allergic disorders such as asthma, acute urticaria and food allergies. ${ }^{3}$ Skin prick test (SPT) is the most effective and cheapest diagnostic method to detect IgE mediated Allergic reactions. ${ }^{4}$ Positive SPT with a history suggestive of clinical sensitivity to identifiable allergens strongly incriminates the allergen as a contributor to Allergic rhinitis.

The type of aeroallergens differ variedly depending on the geographic region and climatic conditions, and in India specially, due to its huge size and varied climatic condition. India, being a populous country with diverse food habits due to socio cultural and communal differences, also afforded

\footnotetext{
* Corresponding author.

E-mail address: poojaarora2312@rediffmail.com (P. Arora).
}

us an opportunity to study the sensitivity to common food allergens in patients of our region. The present study was carried out to identify the patterns of SPT to various types of allergens for avoidance therapy and immunotherapy in patients attending an pulmonary medicine and ENT clinical in tertiary centre and hospitals in Saharanpur.

\section{Materials and Methods}

\subsection{Subjects}

This is a prospective observational study on 50 consecutive patients of allergic rhinitis in an pulmonary and ENT OPDs between July 2018 and June 2019.

After taking clinical history and physical examination of patients in pulmonary medicine and ENT outpatient departments, diagnosis of allergic rhinitis was made on the basis of the Allergic Rhinitis and its impact on Asthma guidelines(2016 revised). ${ }^{5}$ 


\subsection{Inclusion criteria}

Consecutive patients of allergic rhinitis attending the pulmonary medicine and ENT outdoor department, between 10 to 65 years of age group and ready to give informed consent for inclusion in the study and SPT were enrolled.

\subsection{Exclusion criteria}

1. Patients with other causes of rhinitis like vasomotor or atrophic rhinitis

2. Patients in whom skin prick test was negative were also excluded

3. Pregnant and lactating females, patients with ischemic heart disease, patients receiving immunosuppressive medications were also excluded.

\subsection{Clearance and approvals}

Clearance was obtained from the institutional ethic committee. Informed consent in their vernacular language was obtained from the patients.

\subsection{Skin prick test procedure}

The selected patients for SPT were discontinued on medication that interfere with test results, decrease systemic allergic reactions. The allergens were obtained from Creative diagnostic Medicare Private Limited Mumbai The Allergens included 23 Pollens, 4 inscets, 3 mites, 4 types of common dusts, 6 fungi and 6 animal epithelia and histamine and saline as controls. The test procedure consisted of cleaning the skin over flexor aspect of forearm and arm with isopropyl alcohol and allowing it to dry. The skin was marked with a ball point pen to identify and locate the site of each test with a difference of $2 \mathrm{~cm}$ in between the two test sites. A single drop of each test solution was placed. SPT was performed using a sterile lancet. The lancet was placed through the drop of allergens extract at an acute angle to the skin and a shallow lift was made to elevate the small portion of epidermis without inducing bleeding. The lancet was raised for a second before skin was released. This was repeated for each drop of test solution. The lancet was carefully wiped on a dry cotton wool between the tests. Excess solution was removed by placing a tissue over the arm for a moment

The reactions were read after 15 to 20 minutes which appeared as raised wheal and erythema. Both wheal and erythema diameter were measured using a ruler supplied with the allergen kit and the results expressed in $\mathrm{mm}$. Grading of skin prick test was done by comparison to a histamine positive control and a reaction of $>3 \mathrm{~mm}$ than that produced by the negative control on SPT was considered as positive reaction.

The statistical analysis was done using SPSS version 15.0 statistical Analysis Software.

\section{Results}

The age distribution of the patient ranged from 14 to 69 years. Majority of patients belonged to second and third decades without sex predilection in our study. Table 1

A total of 50 patients fulfilling the inclusion criteria were selected and subjected to SPT with 46 allergens in each patient. Thus, a total of 2300 SPTs were done and response was tabulated. Table 2

Maximum numbers of positive $(2+, 3+, 4+)$ SPT was given by pollens in 40 patients $(80 \%)$, followed by dust in 35 patients $(70 \%)$. Mites and insects gave positive SPT in $26(52 \%)$ and $25(50 \%)$ patients respectively, closely followed by fungi in 24 (48\%) patients. Least reaction was given by epithelia in $20 \%$ of patients. Results of positive SPT with varied antigen were tabulated. Tables 3, 4, 5, 6 and 7 .

Table 1: Age distribution of patients

\begin{tabular}{lcc}
\hline Age (Years) & No. of Patients & Percentage \\
$0-9$ & 0 & 0 \\
$10-19$ & 8 & 16 \\
$20-29$ & 14 & 28 \\
$30-39$ & 11 & 22 \\
$40-49$ & 10 & 20 \\
$50-59$ & 05 & 10 \\
$60-69$ & 02 & 04 \\
Total & 50 & 100 \\
\hline
\end{tabular}

Table 2: Positive skin prick test response to various groups of allergens

\begin{tabular}{lcc}
\hline Allergen Subgroups & $\begin{array}{c}\text { No. of } \\
\text { Patients }\end{array}$ & Percentage \\
Mite & 26 & 52 \\
Fungi & 24 & 48 \\
Pollens & 40 & 80 \\
Dust & 35 & 70 \\
Epithelia & 10 & 20 \\
Insects & 25 & 50 \\
\hline
\end{tabular}

\section{Discussion}

The definitive diagnosis of nasal allergy requires identification of allergens and establishment of causal relationship between exposure to allergens and occurrence of relevant symptoms. Identification of allergens is possible by careful history taking and diagnostic procedure such as SPT. SPT is highly sensitive, specific, simple, inexpensive and reproducible investigation for diagnosis of allergic diseases. $^{6}$

The purpose of the study was to determine and characterize common allergens using SPT in patients of allergic rhinitis in a tertiary centre and hospitals of Saharanpur, India. 
Table 3: Results of positive skin tests with various pollen antigens tested

$\begin{array}{lcc}\text { Pollens } & \begin{array}{c}\text { No. of } \\ \text { Patients }\end{array} & \text { Percentage } \\ \text { 1. Cynodon dactylon } & 20 & 40 \\ \text { 2. Parthenium hysterophorus } & 35 & 70 \\ \text { 3. Sorghum vulgare } & 0 & 0 \\ \text { 4. Pennisetum typhoides } & 6 & 12 \\ \text { 5. Amaranthus spinosus } & 20 & 40 \\ \text { 6. Argermone mexicana } & 20 & 40 \\ \text { 7. Xanthium strumariuni } & 0 & 0 \\ \text { 8. Brassica nigra } & 15 & 30 \\ \text { 9. Ageratum conyzoides } & 0 & 0 \\ \text { 10. Cocus nucifera } & 0 & 0 \\ \text { 11. Peltophorum } & 0 & 0 \\ \text { pterocarpum } & & \\ \text { 12. Eucalyputs spp. } & 17 & 34 \\ \text { 13. Ricinus communis } & 21 & 42 \\ \text { 14. Cassia siamea } & 0 & 0 \\ \text { 15.Zea mays } & 0 & 0 \\ \text { 16. Acacia Arabica } & 0 & 0 \\ \text { 17. Prosopis juliflora } & 16 & 32 \\ \text { 18. Carica papaya } & 0 & 0 \\ \text { 19. Ipomoea sp. } & 0 & 0 \\ \text { 20. Helianthus annus } & 15 & 30 \\ \text { 21. Cassia occidentalis } & 0 & 0 \\ \text { 22. Azadirachta indica } & 0 & 0 \\ \text { 23. Mangifera Indica } & 0 & 0 \\ & & \end{array}$

Table 4: Results of positive skin tests with four dusts tested

\begin{tabular}{lcc}
\hline Dust & $\begin{array}{c}\text { No. of } \\
\text { Patients }\end{array}$ & Percentage \\
Cotton Dust & 05 & 10 \\
House dust & 32 & 64 \\
Hay dust & 20 & 40 \\
Grain dust (Rice) & 06 & 12 \\
\hline
\end{tabular}

Table 5: Results of skin prick test with three mite allergens tested

\begin{tabular}{lcc}
\hline Mite & $\begin{array}{c}\text { No. of } \\
\text { Patients }\end{array}$ & Percentage \\
Mite (D-Farine) & 25 & 50 \\
Mite (D-Pteronyssinus) & 9 & 18 \\
Blomia sp. & 6 & 12 \\
\hline
\end{tabular}

Table 6: Results of positive skin prick test with antigenic extracts of various insects tested

\begin{tabular}{lcc}
\hline Insects & No. of Patients & Percentage \\
Ants & 0 & 0 \\
Cockroach & 14 & 28 \\
Housefly & 09 & 18 \\
Mosquito & 04 & 8 \\
\hline
\end{tabular}

Table 7: Results of positive skin prick test given by different fungal antigens tested

\begin{tabular}{lcc}
\hline Fungi & $\begin{array}{c}\text { No. of } \\
\text { Patients }\end{array}$ & Percentage \\
Aspergillus fumigatus & 0 & 0 \\
Aspergillus niger & 15 & 30 \\
Rhizopus nigricans & 4 & 8 \\
Penicillium Sp. & 5 & 10 \\
Candida albicans & 0 & 0 \\
Aspergillus versicolor & 4 & 8 \\
\hline
\end{tabular}

Table 8: Results of positive skin prick test with different epithelial antigens tested

\begin{tabular}{lcc}
\hline Epithelia & $\begin{array}{c}\text { No. of } \\
\text { Patients }\end{array}$ & Percentage \\
Dog epithelia & 5 & 10 \\
Sheep's wool & 0 & 0 \\
Human dander & 0 & 0 \\
Buffalo dander & 7 & 14 \\
Cat epithelia & 3 & 6 \\
Chicken feather & 0 & 0 \\
\hline
\end{tabular}

The most common allergens found in our study were pollen $(80 \%)$, dust $(70 \%)$, mite $(52 \%)$, insects $(50 \%)$, fungi( $48 \%)$ and epithelial antigen(20\%).overall, pollen of Parthenium (70\%) followed by house dust $(64 \%)$ were found to be the most common offending allergens.

The most common allergen in our study was pollen (80\%) and most common among all pollen was pollen of Parthenium, similar to study done by Chaubal and gadve ${ }^{7}$ and it was found to be the second most common allergen after Amaranthus in Bangalore in a study conducted by Anand and Agashi. ${ }^{8}$ Next common offending pollen antigen noted was the pollen of Ricinus in $42 \%$ of the patients. This pollen was found to be the commonest offending allergen by Pherwani et al. ${ }^{9}$

Cynodon, Amaranthus and Argemone gave positive reactions in $40 \%$ of the patients each. Prosopis juliflora gave positive reactions in $32 \%$ of the patients in the present study which is also similar to the study done by Raju et al ${ }^{10}$ who found it is $30 \%$ and Gupta M.C. et al ${ }^{11}$ who found it is $32.46 \%$

Next common group of allergens after pollen antigens that gave positive reaction was dust in $70 \%$ of patients. Among the dust allergens maximum number of positive skin reaction were given by house dust in 32 patients, followed by hay dust in 20 patients, cotton and grain dust (rice) in 6 and 5 patients respectively. House dust was found to give maximum number of positive skin reactions which was similar to study done by Jha et al. ${ }^{12}$ It was found to be the second most common offending dust in a study done by Sethi $\mathrm{S}$ et al, ${ }^{13}$ Pherwani et al ${ }^{10}$ and Shanker et at ${ }^{14}$. Raju et al found grain dust as the most common offending dust, followed by cotton, hay and then house dust. This 
could be due to difference in climatic condition and the other environmental factors of the area where the study was conducted.

House dust mite (D.farine) gave positive reactions in 25 patients $(50 \%)$ and D-Pteronyssius in 9 patients $(18 \%)$ and Blomia species in $6(12 \%)$ patients in the present study. House dust mite (D.farine) gave positive reaction in $50 \%$ of the patients while Singh and Chamyal ${ }^{14}$ reported in $43.3 \%$, Raju et al in $40 \%$ and Pherwani et al in $31.3 \%$ of the patients. It was commoner than the D.Pteronyssimus as also shown by Kashef S. et al. ${ }^{15}$

Estimates suggest that insect comprise $80 \%$ of the world's species. ${ }^{16}$ Dissemination of insects by aircurrents is significant in accounting for seasonal flare-ups of nasobronchial allergy. ${ }^{17}$ In our study cockroach extract gave positive reaction in $28 \%$ of the patients, followed by housefly extracts in $18 \%$ of the patients and mosquito extracts in $8 \%$ of the patients. A maximum number of positive prick test response was given by Cockroach which is similar to study done by Pherwani et at and Chew FT et al. ${ }^{18}$ Raju et al, and Shanker et al ${ }^{19}$ reported maximum number of positive skin reactions in housefly followed by mosquito and cockroach extracts.

Six fungal extracts were used as allergens among which positive reaction was given by four fungal extracts, namely Aspergillus niger in 15 patients (30\%), Aspergillus versicolor and Rhizopus nigricans in four patients each and Penicillum species in five patients. Prasad et al. ${ }^{20}$ In their study by SPT in Lucknow found marked positivity to Aspegillus spp., A.tenuis, F.solani. and R. Nigricans.

Epithelial allergens as a group gave the least positive reaction in only $20 \%$ of the cases. Positive reaction was given by buffalo dander in 7 patients, dog epithelia in 5 patients and cat epithelia in 3 patients. No reaction was given by sheep wool, human dander and chicken feather extracts. Buffalo dander was the most common allergen identified which is in accordance with a study done by Gupta et al. ${ }^{21}$ is probably because most of the patients were from rural area.

The knowledge of common allergens found among study population in our region could assist medical practitioners in narrowing down the panel of allergens tested in daily practice leading to more specificity and cost effectiveness.

\section{Conclusion}

Skin prick test is an invaluable tool for diagnosis and patient management in nasobronchial allergy. Pollens were the most common allergens to which allergy was elicited in our study.

\section{Source of Funding}

No financial support was received for the work within this manuscript.

\section{Conflicts of Interest}

There are no conflicts of interest.

\section{References}

1. Pawankar R. Evidence based guidelines. Allergic rhinitis and its impact on asthma. An update. Japan: ARIA, WHO Initiative; 2001.

2. Patel A, Choudhary S. Prevalence of allergen sensitivity in nasobronchial allergy in Gujarat, India. Natl J Med Res. 2012;2:4314

3. Prasad R, Verma SK, Dua R, Kant S, Kushwaha RAS, Agarwal SP, et al. A study of skin sensitivity to various allergens by skin prick test in patients of nasobronchial allergy. Lung India. 2009;26(3):70-3.

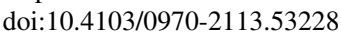

4. Sameer AS, Shera IA, Siddiqi MA, Nayak N, Rasool R, Nissar S, et al. Role of skin prick test in allergic disorders: A prospective study in Kashmiri population in light of review. Indian J Dermatol . 2013;58(1):12-7. 1010104103/0019-5154.105276

5. zek JLB, Bousquet J, Agache I, Agarwal A. Allergic rhinitis and its impact on asthma guidlines- 2016 revision. J Allergy Clinc Immunol. 2017;140(4):950-8.

6. Nanda MS, Devi R. Seasonal variation of allergy profile of patients visiting a tertiary care hospital in hilly areas of Himachal Pradesh. Int J Community Med Public Health . 2018;6(1):146-50. doi:10.18203/2394-6040.1]cmph20185079

7. Chaubal PD, Gadve SB. Study of pollen allergy in Kolhapur during monsoon. Indian J Chest Dis All Sci. 1984;26(1):38-40.

8. Anand P, Agashe SN. Immunological approach to extra mural environmental naso-bronchial allergy. Indian $J$ Otolaryngol. 1984;36(2):39-40.

9. Pherwani AV, Desai AG, Bhave SY. An analysis of skin prick test reactions in asthmatic children in Bombay. Indian J Chest Dis All Sci. 1985;27:219-24.

10. Raju B, Kotilingam K, Rao RM, Rao SG, Bharani SA. Allergic Skin tests in extrinsic asthmatics in Visakhapatnam - A pilot study. Lung India. 1990;8(2):79-83.

11. Gupta MC, Mittal OP, Katyar SK. Pollen allergy in Kanpur. Aspects Allergy App Immunol. 1984;17:99-105.

12. Jha VK, Sundaramma M, Mishra SK, Joshi M. Clinical studies with some airborne pollens and dusts as respiratory allergens around Varanasi. Indian J Chest Dis All Sci. 1975;17:107-21.

13. Sethi S, Sarkar B, Gupta SR. A study of intradermal allergy testing in bronchial asthma. Indian J Chest Dis All Sci. 1986;28(3):105-18.

14. Singh RB, Chamyal PC. Skin test and specific immunotherapy in allergic rhinitis. Indian J Otolaryngol Head Neck Surg. 1994;3(3):138-41.

15. Kashef S, Kashef MA, Eghtedari F. Prevalence of aeroallergens in allergic rhinitis in Shiraz. Iranian J Allergy Asthma Immunol. 2003;2(4):185-8.

16. Chauhan A, Verma SC. Distribution and Diversity of Aquatic Insects in Himachal Pradesh, India: A Review. Int J Current Microbiol Appl Sci. 2016;5(9):273-81. doi:10.20546/1jcmas.2016.509.031.

17. Perlman F. Insects as inhalant allergens; consideration of aerobiology, biochemistry, preparation of material, and clinical observations. $J$ Allergy. 1958;29:302-28.

18. Chew FT, Lim SH, Goh DYT, Lee BW. Sensitization to local dust-mite fauna in Singapore. Allergy. 1999;54(11):1150-68. doi:10.1034/j.1398-9995.1999.00050.x

19. Shanker A, Jain PC, Kumar V. A study of identification of offending allergens in patients of bronchial asthma in Gwalior attending J.A. group of hospitals. Indian J Chest Dis All Sci. 1979;21:166-73.

20. Singh BP, Nath P, Mukerji PK. Air borne fungi of Lucknow city - A study of two sites. Indian J Chest Dis Allied Sci. 1980;22:199-203.

21. Gupta N, Goyal M, Dixit R, Agrawal M, Meena M, Kuldeep R, et al. ALLERGEN SENSITIZATION PROFILE IN PATIENTS OF NASOBRONCHIAL ALLERGY FROM RURAL AND URBAN AREA OF RESIDENCE IN CENTRAL RAJASTHAN. J Evid Based Med Health . 2018;5(7):588-92. doi:10.18410/jebmh/2018/121]. 


\section{Author biography}

Pooja Arora, Assistant Professor
Cite this article: Arora P. A study of skin prick test to identify common

allergens in allergic rhinitis patients in and around Saharanpur. IP J

Diagn Pathol Oncol 2021;6(2):94-98. 